\title{
Preparation, Characterization and Biological Studies of Adducts of Bis( $O$-isopropyldithiocarbonato)oxovanadium(IV) with Nitrogen Donor Ligands
}

\author{
NEERUPAMA*, DEEPSHIKHA KHAJURIA, POOJA SHARMA and RENU SACHAR \\ Department of Chemistry, University of Jammu, Babasaheb Ambedkar Road, \\ Jammu-180006, India \\ neeru.s1211@gmail.com
}

Received 3 September 2014 / Accepted 25 September 2014

\begin{abstract}
A series of adducts of bis(O-isopropyldithiocarbonato)oxovanadium(IV) with substituted pyridines have been synthesized by treating bis( $O$-isopropyldithiocarbonato)oxovanadium(IV) with substituted pyridines in acetone in equimolar ratios. Analytical results show that the adducts have 1:1 stoichiometry with general formula $\mathrm{VO}(O$-isopropyldithiocarbonato $) 2 \mathrm{~L}$ where $\mathrm{L}=2$ and 3-bromopyridine; 4-acetylpyridine; 3-hydroxypyridine; 2-methoxypyridine; 2-amino-3-methylpyridine; 2-amino-4-methylpyridine; 2-amino-6-methylpyridine). The addition complexes have been characterized by elemental analysis, conductivity measurements, magnetic susceptibility measurements, infrared and electronic spectral studies. These studies suggest a distorted octahedral structure and paramagnetic nature of the adducts. Antifungal activity of some adducts have been carried out against the fungal strain Sclerotium rolfsii.
\end{abstract}

Keywords: Oxovanadium(IV), O-isopropyldithiocarbonate, Sclerotium rolfsii

\section{Introduction}

Among sulphur donating ligands, 1:1 dithiolates which include dithiocarbamates, xanthtes and dithiocarboxylates have invited much research attention from chemists, physicists, biologists due to diverse applications and interesting biological, structural, magnetic, electrochemical and therml activities ${ }^{1-3}$. An important use of xanthates is the selective benefication of galena and sphalerite recently they have also been used as collectors of nonsulphide ores such as cerussite and anglesite ${ }^{4-5}$. Xanthate of certain transition metals are used as accelerators in vulcanization of rubber brought a new revolution in the rubber industry ${ }^{6}$. Xanthate have recently been shown to inhibit the replication of both DNA and RNA viruses in vitro. It was found that certain xanthate derivatives exhibit beneficial antimicrobial and antiviral effects ${ }^{7}$. Here we report synthesis and investigation of the 1:1 adducts of some adducts of oxovanadium(IV)xanthates with substituted pyridines such as 2 and 3-bromopyridine; 4-acetylpyridine; 3-hydroxypyridine; 2-methoxypyridine; 2-amino-3methylpyridine; 2-amino-4-methylpyridine and 2-amino-6-methylpyridine. 


\section{Experimental}

Potassium salt of isopropyl xanthate was prepared by the method reported in literature ${ }^{8}$. Into a $500 \mathrm{~mL}$ round bottomed flask, fitted with a reflux condenser, was placed $42 \mathrm{~g}(0.75 \mathrm{~mol})$ of potassium hydroxide pellets and $192.71 \mathrm{~g}(234.72 \mathrm{~mL}, 2.6 \mathrm{~mol})$ of isopropyl alcohol. The reaction mixture was heated under reflux for $1 \mathrm{~h}$. The mixture was then cooled and liquid from the residual solid was decanted off into another dry $500 \mathrm{~mL}$ flask. To this flask, was added $52 \mathrm{~g}(45 \mathrm{~mL}, 0.75 \mathrm{~mol})$ of carbon disulphide slowly with constant shaking. The residual solid mass was filtered (after cooling in ice) on a sintered glass funnel at the pump. It was washed with three $25 \mathrm{~mL}$ portions of ether. The resulting potassium $O$-isopropyldithiocarbonate (potassium salt of isopropyl xanthate) was dried in a vacuum dessicator over anhydrous calcium chloride. It was then recrystallized from absolute ethanol.

\section{Preparation of bis(O-isopropyldithiocarbonato)oxovanadium(IV)}

The saturated aqueous solutions of hydrated vanadyl sulfate (1.63 g, $0.01 \mathrm{~mol})$ and potassium $O$-isopropyldithiocarbonate ( $3.48 \mathrm{~g}, 0.02 \mathrm{~mol}$ ) were prepared separately and then mixed with constant stirring. Dark green precipitates were formed which were filtered immediately and were dried in a vacuum desiccator over anhydrous calcium chloride. The composition of the complex was established to be $\mathrm{VO}\left[\mathrm{S}_{2} \mathrm{C}\left(\mathrm{O}-\mathrm{C}_{3} \mathrm{H}_{7}\right)\right]_{2}$ by the elemental analysis.

\section{Preparation of 1:1 adducts of Bis(O-isopropyldithiocarbonato)oxovanadium(IV) with substituted pyridines}

The 1:1 addition complexes of bis( $O$-isopropyldithiocarbonato)oxovanadium(IV) with substituted pyridines were prepared by stirring $\mathrm{VO}\left[\mathrm{S}_{2} \mathrm{C}\left(\mathrm{O}-\mathrm{C}_{3} \mathrm{H}_{7}\right)\right]_{2}(0.927 \mathrm{~g}, 0.0026 \mathrm{~mol})$ in acetone with substituted pyridines [2-bromopyridine $=0.410 \mathrm{~g} ; 3$-bromopyridine $=0.410 \mathrm{~g}$; 4-acetylpyridine $=0.314$; 3-hydroxypyridine $=0.247$ g; 2-methoxypyridine $=0.287$ g; 2-amino3-methylpyridine=0.2511 g; 2-amino-4-methylpyridine=0.2511 g; 2-amino-6-methylpyridine = $0.2511 \mathrm{~g}(0.0026 \mathrm{~mol})]$ for $30 \mathrm{~min}$. The contents of the reaction mixture were allowed to stand for 20-24 h and the green obtained was washed with the solvent used in their preparation and dried over calcium chloride at room temperature (Scheme 1).

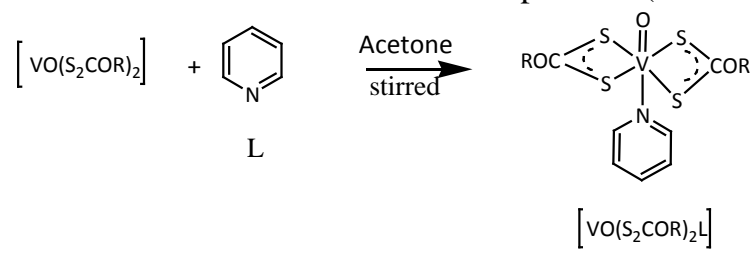

Where $\mathrm{R}=\mathrm{C}_{3} \mathrm{H}_{7} \mathrm{~L}=2$ and 3-bromopyridine; 4-acetylpyridine; 3-hydroxypyridine; 2-methoxypyridine; 2-amino-3-methylpyridine; 2-amino-4-methylpyridine; 2-amino-5-methylpyridine

Scheme 1. Method of preparation and proposed structure of the 1:1 adducts

\section{Methods}

Carbon, Hydrogen, Nitrogen and Sulfur were determined on elemental analyzer (elemental vario EL III, carlo Erba 1108). Molar conductance was determined on the millimolar solution in DMF using century CC 601 Conductivity Bridge. Infrared spectra of the complexes over the region 4,000-200 $\mathrm{cm}^{-1}$ were recorded using $\mathrm{KBr}$ pellets on Infrared spectrophotometer (Perkin Elmer FT-IR). The electronic spectra of the adducts were recorded in DMF on systronics 119 UV-Visible spectrophotometer. Magnetic moments were determined at room temperature by VSM method (Princeton Applied Research-Model No. 155). 
Thermogravametric analysis (TGA/DTA) of the complexes was recorded on Diamond TGA/DTA Thermoanalyzer at the heating rate of $10{ }^{\circ} \mathrm{C} / \mathrm{min}$ in the temperature range $30-1000{ }^{\circ} \mathrm{C}$ at NIT Pune and Linseis STA-PT-thermoanalyzer. The analytical data, molar conductance and magnetic moments of the adducts isolated are presented in the Tables $1 \& 2$.

\section{Results and Discussion}

The adducts of bis(O-isopropyldithiocarbonato)oxovanadium(IV) are microcrystalline solids and are characterized by various physicochemical techniques. These adducts are insoluble in common organic solvents such as benzene, acetone, toluene, 1,4-dioxane, nitrobenzene, ethanol etc. However these adducts are soluble in dimethylformamide and dimethylsulfoxide. The elemental analysis reveals that the adducts isolated have 1:1 stoichiometry depending upon the molar ratios of metal and ligand taken for their preparation (Table 1 ).

Table 1. Analytical data of 1:1 adducts of bis( $O$-isopropyldithiocarbonato)oxovanadium(IV) with substituted pyridines

\begin{tabular}{|c|c|c|c|c|c|c|}
\hline \multirow[t]{2}{*}{ S.No. } & \multirow[t]{2}{*}{ Name of the adduct } & \multicolumn{5}{|c|}{ Analysis Found (Calculated), \% } \\
\hline & & $\bar{C}$ & $\mathrm{H}$ & $\mathrm{N}$ & $\mathrm{S}$ & $\mathrm{V}$ \\
\hline \multirow[t]{2}{*}{1} & Bis(O-isopropyldithiocarbonato) & 30.70 & 3.10 & 1.83 & 24.80 & 9.78 \\
\hline & (2-bromopyridine)oxovanadium(IV) & $(31.51)$ & (3.63) & $(2.82)$ & $(25.86)$ & (10.29) \\
\hline \multirow[t]{2}{*}{2} & $\operatorname{Bis}(O$-isopropyldithiocarbonato) & 30.90 & 3.11 & 1.94 & 24.75 & 9.89 \\
\hline & (3-bromopyridine)oxovanadium(IV) & $(31.51)$ & $(3.63)$ & $(2.82)$ & $(25.86)$ & $(10.29)$ \\
\hline \multirow[t]{2}{*}{3} & Bis(O-isopropyldithiocarbonato) & 36.74 & 4.15 & 2.78 & 27.48 & 10.75 \\
\hline & $\begin{array}{l}\text { (2-methoxypyridine)oxo- } \\
\text { vanadium(IV) }\end{array}$ & $(37.67)$ & $(4.70)$ & (3.13) & $(28.70)$ & $(11.42)$ \\
\hline \multirow[t]{2}{*}{4} & $\operatorname{Bis}(O$-isopropyldithiocarbonato) & 38.94 & 4.05 & 2.59 & 26.95 & 10.75 \\
\hline & adium(IV) & $(39.30)$ & $(4.58)$ & $(3.05)$ & $(27.95)$ & $(11.12)$ \\
\hline \multirow[t]{2}{*}{5} & $\operatorname{Bis}(O$-isopropyldithiocarbonato) & 35.84 & 3.94 & 2.98 & 28.73 & 10.65 \\
\hline & (3-hydroxypyridine) oxovanadium(IV) & $(36.11)$ & $(4.30)$ & (3.24) & $(29.63)$ & (11.79) \\
\hline \multirow[t]{2}{*}{6} & Bis(O-isopropyldithiocarbonato) & 36.55 & 4.11 & 5.61 & 27.81 & 10.50 \\
\hline & $\begin{array}{l}\text { (2-amino-3-methylpyridine) } \\
\text { oxovanadium(IV) }\end{array}$ & $(37.75)$ & $(4.94)$ & $(6.29)$ & $(28.76)$ & $(11.44)$ \\
\hline \multirow[t]{2}{*}{7} & $\operatorname{Bis}(O$-isopropyldithiocarbonato) & 36.91 & 4.25 & 5.87 & 27.10 & 10.99 \\
\hline & $\begin{array}{l}\text { (2-amino-4-methylpyridine) } \\
\text { oxovanadium(IV) }\end{array}$ & $(37.75)$ & $(4.94)$ & $(6.29)$ & $(28.76)$ & $(11.44)$ \\
\hline \multirow[t]{2}{*}{8} & Bis(O-isopropyldithiocarbonato) & 36.50 & 4.31 & 5.93 & 27.15 & 10.96 \\
\hline & $\begin{array}{l}\text { (2-amino-6-methylpyridine) } \\
\text { oxovanadium(IV) }\end{array}$ & (37.75) & $(4.94)$ & (6.29) & (28.76) & $(11.44)$ \\
\hline
\end{tabular}

The structures of the isolated complexes were established from their molar conductance measurements, magnetic susceptibility measurements, electronic and infrared spectral data. The results of these investigations are tabulated and discussed. The molar conductance value of their millimolar solutions in DMF are found in the range of 3.48-7.54 ohm $\mathrm{mole}^{-1} \mathrm{~cm}^{2}$. These values are lower than the values which can be expected for uni-univalent electrolytes in these solvents suggesting that these complexes are neutral and non-ionic in character. These values are lower than the values expected for any uni-univalent electrolytes in this solvent suggesting that these complexes are neutral and nonionic in character ${ }^{9}$ (Table 2). The $\mathrm{VO}^{2+}$ cation, being $\mathrm{d}^{1}$ ion, possesses a spin only magnetic moment value of 1.73 B.M corresponding to one unpaired electron ${ }^{10}$. The adducts of (O-isopropyldithiocarbonato) oxovanadium(IV) exhibit magnetic moments in the range 1.79-2.13 B.M and the values of 
magnetic moments are presented in (Table 2). The values are in accordance with the paramagnetic nature of these adducts due to the presence of unpaired electron. It also suggests that the adducts of oxovanadium(IV) have octahedral geometry and are monomeric in nature. The higher value of magnetic moment may be due to the orbital contribution.

Table 2. Molar conductance and magnetic data of $1: 1$ adducts of bis $(O$ isopropyldithiocarbonato)oxovanadium(IV) with substituted pyridines

\begin{tabular}{clccc}
\hline \multirow{2}{*}{ S.No. } & \multicolumn{1}{c}{ Name of the adduct } & \multicolumn{1}{c}{$\begin{array}{c}\text { Molar } \\
\text { conductance } \\
\mathrm{Ohm}^{-1} \mathrm{~mol}^{-1} \mathrm{~cm}^{2}\end{array}$} & $\begin{array}{c}\text { Magnetic } \\
\text { B.M }\end{array}$ & Temp. \\
\hline 1 & $\begin{array}{l}\text { Bis(O-isopropyldithiocarbonato) } \\
\text { (2-bromopyridine)oxovanadium(IV) }\end{array}$ & 6.63 & 1.75 & 298 \\
2 & $\begin{array}{l}\text { Bis(O-isopropyldithiocarbonato) } \\
\text { (3-bromopyridine)oxovanadium(IV) }\end{array}$ & 6.01 & 1.71 & 298 \\
3 & $\begin{array}{l}\text { Bis(O-isopropyldithiocarbonato) } \\
\text { (2-methoxypyridine)oxovanadium(IV) }\end{array}$ & 5.55 & 1.81 & 298 \\
4 & $\begin{array}{l}\text { Bis(O-isopropyldithiocarbonato) } \\
\text { (4-acetylpyridine)oxovanadium(IV) }\end{array}$ & 6.15 & 1.83 & 298 \\
5 & $\begin{array}{l}\text { Bis(O-isopropyldithiocarbonato) } \\
\text { (3-hydroxypyridine)oxovanadium(IV) } \\
6\end{array}$ & 4.31 & 1.79 & 298 \\
Bis(O-isopropyldithiocarbonato) \\
$\begin{array}{l}\text { (2-amino-3-methylpyridine) } \\
\text { oxovanadium(IV) }\end{array}$
\end{tabular}

The infrared spectra of the adducts of oxovanadium(IV)xanthates exhibit a strong band in the range $996-960 \mathrm{~cm}^{-1}$ which is attributed to the terminal $\mathrm{V}=\mathrm{O}$ bond. These values are within the range observed for monomeric $\mathrm{VO}^{2+}$ complexes ${ }^{11-13}$. In the present work a single sharp band of high intensity has been observed in all the complexes in the range of $1035-1045 \mathrm{~cm}^{-1}$ range. The appearance of only C-S band suggests symmetrical bidentate binding of the xanthate moiety. There is a positive shift of $10-30 \mathrm{~cm}^{-1}$ in comparison to the free ligands. This indicates that the xanthate ligand coordinates with the metal through sulfur atoms. Moreover, the complexes show a band in the region 1190$1220 \mathrm{~cm}^{-1}$ which is attributed to $v(\mathrm{C}-\mathrm{O})$ of xanthate moiety (Table 3). The corresponding band in the ligand appeared at lower frequency. A comparison of the infrared spectral data of complexes with their respective adducts reveals that $\mathrm{V}=\mathrm{O}$ band in the parent complex (1000-980 $\left.\mathrm{cm}^{-1}\right)$ gets displaced to lower frequencies $\left(990-960 \mathrm{~cm}^{-1}\right)$ in the adducts ${ }^{12,14,15}$. This displacement can be attributed to the electronic donation of the base to the vanadium $\left(\mathrm{N}^{-} \mathrm{V}\right)$, which increases the electron density on the metal $d$-orbitals and consequently the $\mathrm{p}_{\pi}-\mathrm{d}_{\pi}$ donation from oxygen atom to vanadium is expected to be reduced. The electronic spectra of the adducts of oxovanadium(IV)xanthates with substituted pyridine, prepared in the present work, were recorded in dimethylformamide. The electronic spectra data of the adducts of oxovanadium(IV)bis(O-isopropyldithiocarbonate) show three bands in the range 
$12255-15935 \mathrm{~cm}^{-1}, 15925-19043 \mathrm{~cm}^{-1}$ and 22550-29265 $\mathrm{cm}^{-1}$ and are assigned to e $\leftarrow \mathrm{b}_{2}$, $\mathrm{b}_{1} \leftarrow \mathrm{b}_{2}$ and $\mathrm{a}_{1} \leftarrow \mathrm{b}_{2}$ transitions respectively are presented in (Table 3) These bands are characteristic of oxovanadium(IV) complexes in octahedral environment ${ }^{16,17}$.

Table 3. Electronic and Infrared spectral data of 1:1 adducts of bis $(O$-isopropyldithiocarbonato)oxovanadium(IV) with substituted pyridines

\begin{tabular}{|c|c|c|c|c|c|c|c|c|}
\hline \multirow[t]{2}{*}{ S.N } & \multirow[t]{2}{*}{ Name of the adduct } & \multicolumn{3}{|c|}{$\begin{array}{l}\text { Electronic spectral } \\
\text { data, } \mathrm{cm}^{-1}\end{array}$} & \multicolumn{4}{|c|}{ Infrared spectral data, $\mathrm{cm}^{-1}$} \\
\hline & & $v 1$ & $v 2$ & v3 & $v(\mathrm{C}-\mathrm{S})$ & $v(\mathrm{C}-\mathrm{O})$ & $v(\mathrm{~V}=\mathrm{O}$ & $v(\mathrm{~V}-\mathrm{S})$ \\
\hline 1 & $\begin{array}{l}\text { Bis }(O \text {-isopropyldithiocarbonato) } \\
\text { (2-bromopyridine) } \\
\text { oxovanadium(IV) }\end{array}$ & 13034 & 17745 & 12480 & 1031 & 1148 & 972 & 411 \\
\hline 2 & $\begin{array}{l}\text { Bis }(O \text {-isopropyldithiocarbonato) } \\
\text { (3-bromopyridine) } \\
\text { oxovanadium(IV) }\end{array}$ & 14651 & 16891 & 25041 & 1035 & 1145 & 971 & 410 \\
\hline 3 & $\begin{array}{l}\text { Bis }(O \text {-isopropyldithiocarbonato) } \\
\text { (2-methoxypyridine) } \\
\text { oxovanadium(IV) }\end{array}$ & 14299 & 17519 & 25213 & 1037 & 1142 & 975 & 400 \\
\hline 4 & $\begin{array}{l}\text { Bis }(O \text {-isopropyldithiocarbonato) } \\
\text { (4-acetylpyridine) } \\
\text { oxovanadium(IV) }\end{array}$ & 15111 & 16882 & 23081 & 1032 & 1144 & 976 & 414 \\
\hline 5 & $\begin{array}{l}\text { Bis }(O \text {-isopropyldithiocarbonato) } \\
\text { (3-hydroxypyridine) } \\
\text { oxovanadium(IV) }\end{array}$ & 13961 & 18599 & 24661 & 1039 & 1130 & 977 & 415 \\
\hline 6 & $\begin{array}{l}\text { Bis }(O \text {-isopropyldithiocarbonato) } \\
\text { (2-amino-3-methylpyridine) } \\
\text { oxovanadium(IV) }\end{array}$ & 15012 & 18235 & 23731 & 1034 & 1144 & 973 & 404 \\
\hline 7 & $\begin{array}{l}\text { Bis }(O \text {-isopropydithiocarbonato) } \\
\text { (2-amino-4-methylpyridine) } \\
\text { oxovanadium(IV) }\end{array}$ & 13841 & 18121 & 25691 & 1036 & 1139 & 970 & 413 \\
\hline 8 & $\begin{array}{l}\text { Bis( } O \text {-isopropyldithiocarbonato) } \\
\text { (2-amino-6-methylpyridine) } \\
\text { oxovanadium(IV) }\end{array}$ & 15691 & 17612 & 24650 & 1031 & 1145 & 972 & 415 \\
\hline
\end{tabular}

\section{Thermogravimetrical Analysis}

The TGA graph (Table 1) of bis(O-isopropyldithiocarbonato)(2-bromopyridine)oxovanadium(IV) shows a stepwise loss of weight with the rise of temperature. The first step is observed at $386.9^{\circ} \mathrm{C}$ which may be due to loss of 2-bromopyridine (calculated $=33.2 \%$, found $=31.98 \%$ ) which is followed by significant loss of weight was observed at $796.9{ }^{\circ} \mathrm{C}$ which is due to loss of two xanthate moieties. After this there is a gradual loss of weight till at a temperature near $796.9^{\circ} \mathrm{C}$ the weight resultant mass was found corresponding to formation of $\mathrm{V}_{2} \mathrm{O}_{5}$ as a stable product.

\section{Biological studies}

The antifungal activity of the adducts was tested by Poisoned food technique against the pathogenic fungus Sclerotium rolfsii. The linear growth of the fungus in controlled manner was recorded at different concentration of the adducts. The growth inhibition of Sclerotium rolfsii over control was calculated (Table 4). It is found that on increasing the concentration of the adducts, the colony diameter of the fungus decreases and hence percent inhibition increases ${ }^{18}$ (Figure 2). The growth inhibition of Fungus over control was calculated as: 
$\%$ Inhibition $(\mathrm{I})=\mathrm{C}-\mathrm{T} / \mathrm{C} \times 100$

Where $\mathrm{I}=$ percent inhibition, $\mathrm{C}=$ mean growth of fungus (in $\mathrm{mm}$ ) in control and $\mathrm{T}=$ mean growth of fungus $($ in $\mathrm{mm})$ in treatment.

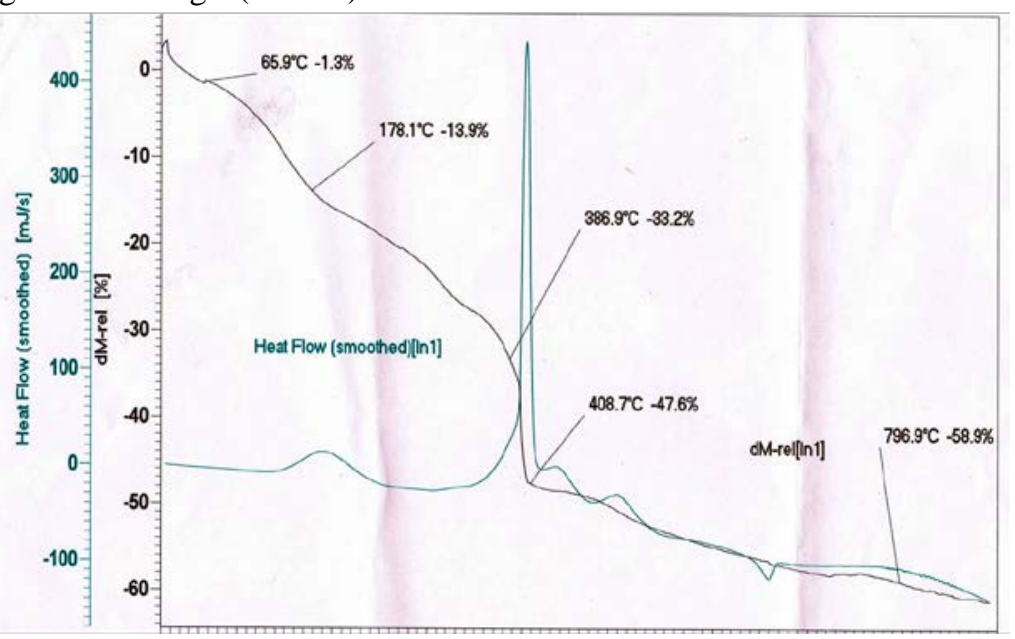

Figure 1. TGA of the adduct bis(O-isopropyldithiocarbonato)(2-bromopyridine) oxovanadium(IV)

Table 4. In vitro evaluation against Sclerotium Rolfsii, Mean Colony Diameter $=90 \mathrm{~mm}$

\begin{tabular}{|c|c|c|c|c|}
\hline S.No & Name of the adduct & $\begin{array}{c}\text { Concentration } \\
\text { ppm }\end{array}$ & $\begin{array}{c}\text { Colony } \\
\text { diameter, } \mathrm{mm}\end{array}$ & $\begin{array}{c}\% \text { inhibition }(\mathrm{I})= \\
{[(\mathrm{C}-\mathrm{T}) / \mathrm{C}] \times 100}\end{array}$ \\
\hline \multirow[t]{4}{*}{1} & Bis(O-isopropyldithiocarbonato) & 50 & 60 & 33.33 \\
\hline & (2-bromopyridine)oxovanadium(IV) & 100 & 30 & 66.67 \\
\hline & & 150 & 10 & 88.89 \\
\hline & & 200 & 2 & 97.78 \\
\hline \multirow[t]{4}{*}{2} & Bis(O-isopropyldithiocarbonato) & 50 & 50 & 44.44 \\
\hline & (4-acetylpyridine)oxovanadium(IV) & 100 & 26.5 & 70.56 \\
\hline & & 150 & 11.2 & 87.56 \\
\hline & & 200 & 4.1 & 95.44 \\
\hline \multirow[t]{4}{*}{3} & Bis(O-isopropyldithiocarbonato) (3- & 50 & 35 & 6.11 \\
\hline & hydroxypyridine)oxovanadium(IV) & 100 & 20 & 77.78 \\
\hline & & 150 & 10.5 & 88.33 \\
\hline & & 200 & 3.2 & 96.44 \\
\hline
\end{tabular}

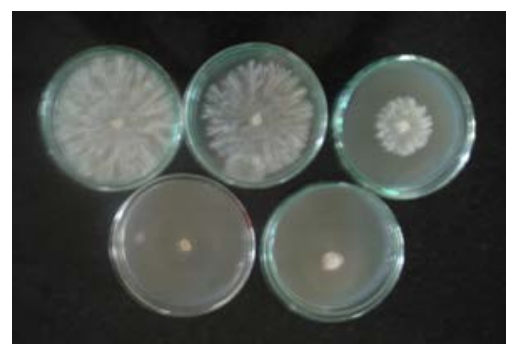

(a)

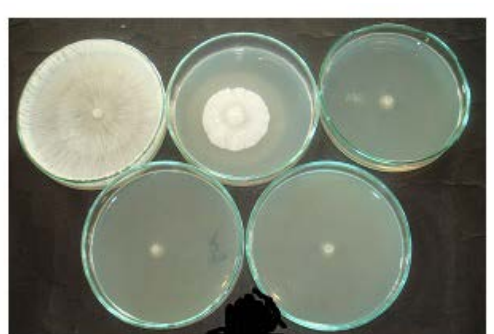

(b) 


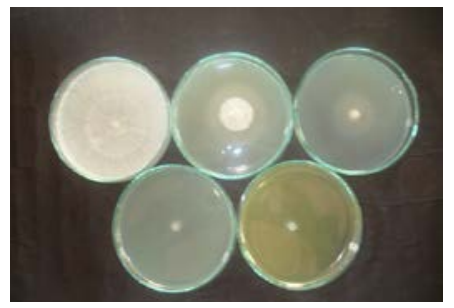

(c)

Figure 2. Antifungal activity of (a) $\mathrm{Bis}(\mathrm{O}$-isopropyidithiocarbonato)(2-bromopyridine) oxovanadium(IV), (b) Bis(O-isopropyldithiocarbonato)(4-acetylpyridine)oxovanadium(IV), (c) $\operatorname{Bis}(O$-isopropyldithiocarbonato)(3-hydroxypyridine)oxovanadium(IV)

\section{References}

1. Casas J S, Castellano E E, Ellena J, Haiduc I, Sanchez A, Semeniuc R F and Sordo J, Inorganica Chimica Acta, 2002, 329(1), 71-78; DOI:10.1016/S0020-1693(01)00820-9

2. Gushchin A L, Llusar R, Vicent C, Abramov P A and Garcia C J G, Eur J Inorg Chem.., online, 2013, 14, 2615-2622; DOI:10.1002/ejic.201201532

3. Solak S, Aydemir C, Karakus M and Lönnecke P, Chem Central J., 2013, 7, 89-96; DOI:10.1186/1752-153X-7-89

4. Oliveira C R, Rubio J, Int J Mineral Process., 2009, 90(1-4), 21-26; DOI:10.1016/j.minpro.2008.09.006

5. Chanturia V A, Kurkov A V and Pastukhova I V, J Mining Sci., 2006, 42(4), 374-386; DOI:10.1007/s10913-006-0066-z

6. Palaty S, Devi P V and Joseph R, J Appl Polym Sci., 2011, 122(2), 1325-1332; DOI:10.1002/app.34057

7. Friebolin W, Schilling G, Zoller M and Amtmann E, J Med Chem., 2005, 48(25), 79257931; DOI:10.1021/jm0408991

8. Furniss B S, Hannaford A J, Smith P W G and Tatchell A R, Vogel's Text Book of Practical Organic Chemistry, Pearson Education, London, UK, $5^{\text {th }}$ Edition, 1989.

9. Geary W J, Coord Chem Rev., 1971, 7(1), 81-122; DOI:10.1016/S00108545(00)80009-0

10. Bakir J A Jeragh and Ali El-Dissouky, Trans Metal Chem., 2004, 29(6), 579-585; DOI:10.1007/s11243-004-5580-0

11. Callahan K P and Durand P J, Inorg Chem., 1980, 19(11), 3211-3217; DOI:10.1021/ic50213a002

12. Sharma N, Kumar V, Sharma R, Kumari M and Kanwar S S, Bull Chem Soc Chem., 2011, 84(8), 855-861.

13. Malik V, Solanki G and Singh V, Oriental J Chem., 2009, 25(4), 1041-1046.

14. Han H, Lu L, Wang Q, Zhu M, Yuan C, Xing S and Fu X, Dalton Trans., 2012, 41, 11116-11124; DOI:10.1039/C2DT30198A

15. Sreeja P B and Prathapachandra Kurup M R, Spectrochimica Acta Part A: Molecular Biomolecular Spectroscopy, 2005, 61(1-2), 331-336; DOI:10.1016/j.saa.2004.04.001

16. Parihar S, Pathan S, Jadeja R N, Patel A and Gupta V K, Inorg Chem.., 2011, 51(2), 1152-1161; DOI:10.1021/ic202396q

17. Maurya M R, Coord Chem Rev., 2003, 237(1-2), 163-181; DOI:10.1016/S00108545(02)00293-X

18. Nene Y L and Thapliyal P N, Fungicides in Plant Disease Control, III Edn., 1993, 691. 